\title{
Pengaruh Pemberian Omega-3 Terhadap Kadar C-Reactive Protein pada Remaja Obes Resistensi Insulin
}

\author{
Wilson, ${ }^{*}$ Eka Agustia Rini, ${ }^{*}$ Hafni Bachtiar** \\ ${ }^{*}$ Bagian Ilmu Kesehatan Anak, ${ }^{* *}$ Bagian Ilmu Kesehatan Masyarakat RSUP Dr.M.Djamil, Fakultas Kedokteran Universitas \\ Andalas, Padang
}

Latar belakang. Obesitas berperan penting terhadap terjadinya sindrom metabolik yang dapat menyebabkan resistensi insulin, dislipidemia, diabetes mellitus dan hipertensi yang akan meningkatkan risiko penyakit jantung koroner. Jaringan adiposa pada obesitas akan memproduksi berbagai sitokin antara lain TNF- $\alpha$ dan IL- 6 yang selanjutnya merangsang hati untuk menghasilkan C-RP. Omega-3 mempunyai efek anti inflamasi, dapat meningkatkan sensitifitas insulin, mengurangi resistensi insulin, perlemakan hati dan memperbaiki profil lemak serta menurunkan kadar C-RP.

Tujuan. Mengetahui pengaruh pemberian Omega-3 terhadap kadar C-RP pada remaja obesitas resistensi insulin.

Metode. Penelitian eksperimental dari November 2011 sampai Maret 2012 dengan disain pre and post-test group. Obesitas ditentukan berdasarkan pengukuran indek massa tubuh (IMT) $>$ p-95 WHO-NCHS, resistensi insulin menurut kadar homeostasis model assesmentinsulin resistence (HOMA-IR) >3,16. Sampel terpilih diperiksa kadar C-RP sebelum dan sesudah pemberian Omega-3. Omega-3 diberikan selama 3 bulan dengan dosis $250 \mathrm{mg}$ perhari. C-RP diperiksa secara Elisa dengan metode CMIA (chemiluminescent Immunometriz assay), sensitivitas $0,01 \mathrm{mg} / \mathrm{dL}$. Data diolah menggunakan paired t-test $(\alpha=0,05)$.

Hasil. Didapatkan 75 orang remaja obesitas dan 21 orang di antaranya (50,7\%) mengalami resistensi insulin. Sebanyak 21 sampel diuji, lebih dari separuh laki-laki $(57,1 \%$ vs $42,9 \%)$. Rerata umur $16 \pm 0,68$ tahun, rerata IMT $32,88 \pm 2,44 \mathrm{~kg} / \mathrm{m}^{2}$. Rerata $\mathrm{kadar}$ glukosa, insulin puasa dan HOMA-IR, masing-masing adalah 90,36 $\pm 14,94 \mathrm{mg} / \mathrm{dl}, 20,89 \pm 4,19 \mu \mathrm{IU} / \mathrm{L}$ dan 4,52 $\pm 0,89$. Terdapat

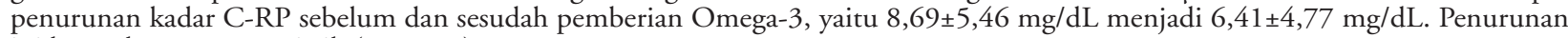
ini bermakna secara statistik $(\mathrm{p}=0,018)$.

Kesimpulan. Konsumsi Omega-3 selama 3 bulan menurunkan kadar C-RP remaja obesitas resistensi insulin. Sari Pediatri 2015;17(1):41-6.

Kata kunci : obesitas, resistensi insulin, Omega-3, C-RP

\section{The Effect of Omega-3 Supplementation to C-Reactive Protein Level in Obes Adolescent with Insulin Resistance}

\author{
Wilson, ${ }^{*}$ Eka Agustia Rini, ${ }^{*}$ Hafni Bachtiar**
}

Background. Obesity plays an important rule in metabolic syndrome which eventually can lead to insulin resistance, dyslipidemia, diabetes mellitus and hypertension that finally will increase risk of coronary heart disease. Adipose tissue in obesity will induce various kind of cytokines production, for example TNF- $\alpha$ and IL-6, that can stimulate the liver to produce C-RP. Omega-3 having anti-inflammatory effects, can increase insulin sensitivity, decreases insulin resistance, fatty liver development, repairs lipid profile and decreases C-RP level.

Objective. To know the effect of Omega-3 supplementation on the C-RP level in obese adolescent with insulin resistance

Method. An experimental study was conducted from November 2011 until March 2012, using pre and post-test group design. Obesity defined as body mass index (BMI) > p-95 WHO-NCHS. Insulin resistance was marked on homeostasis model assessment-insulin Resistance (HOMA-IR) >3.16. The C-RP level was examined before and after Omega-3 supplementation, which was given for 3 months, withdaily dose of $250 \mathrm{mg}$. The C-RP was examined using ELISA with CMIA (Immunometriz chemiluminescent assay) method. The sensitivity was $0.01 \mathrm{mg} / \mathrm{dL}$. Data were calculated using paired t-test $(\alpha=0.05)$.

Results. There were 75 obese adolescents, and 38 (50.7\%) of those have the insulin resistance. However only 21 adolescents agreed to participate as the study sample, with 12 of them are boys $(57.1 \%$ vs $42.9 \%)$. The average age was $16 \pm 0.68$ years old, the average BMI wass $32.88 \pm 2.44 \mathrm{~kg} / \mathrm{m} 2$. The average glucose level, fasting insulin and HOMA-IR were $90.36 \pm 14.94 \mathrm{mg} / \mathrm{dl}, 20.89 \pm 4.19$ $\mu \mathrm{IU} / \mathrm{L}$ and $4.52 \pm 0.89$ respectively. C-RP level before and after supplementation Omega-3 were 8.69 $\pm 5.46 \mathrm{mg} / \mathrm{dL}$ and $6.41 \pm 4.77$ $\mathrm{mg} / \mathrm{dL}$.

Conclusion. The consumption of Omega-3 supplementation for 3 months could decrease C-RP level in obese adolescent with insulin resistance. Sari Pediatri 2015;17(1):41-6.

Keyword: obesity, insulin resistance, Omega-3, C-RP

Alamat korespondensi: Dr. Wilson. Bagian Ilmu Kesehatan Anak RSUP Dr.M.Djamil, Fakultas Kedokteran Universitas Andalas, Padang. Jl.

Perintis Kemerdekaan, Padang. E-mail: wilson_apollo3@yahoo.com 


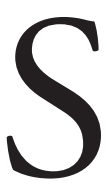
aat ini, peningkatan prevalensi obesitas tidak saja di negara maju, tetapi juga di negara berkembang sehingga merupakan masalah global. ${ }^{1}$ National health and nutrition examination survey (NHANES) tahun 2012 melaporkan terdapat peningkatan jumlah remaja obesitas usia 12-19 tahun dari 5\% pada tahun 1976-1980 menjadi 18,4\% pada tahun 2009-2010. ${ }^{2}$ Beberapa penelitian menyimpulkan obesitas berperan penting terhadap gangguan yang disebut sindrom metabolik yang dapat mengakibatkan dislipidemia, diabetes mellitus tipe 2, dan hipertensi yang akhirnya meningkatkan risiko penyakit jantung koroner (PJK). ${ }^{3-6}$

Pada pasien obesitas, intervensi nutrisi dari awal akan mengurangi risiko sindrom metabolik. Salah satu diet yang dianjurkan berupa konsumsi Omega-3 yang terdapat dalam minyak ikan dan beberapa jenis kacang-kacangan. ${ }^{7-9}$ Omega-3 merupakan asam lemak rantai panjang dengan bentuk aktifnya docohexanoic acid (DHA) dan eicosapentanoic acid (EPA) yang mempunyai efek anti inflamasi dengan meningkatkan lipolisis triasilgliserol, oksidasi asam lemak, HDL-c (high density lipoprotein-cholesterol), dan sensitifitas insulin., ${ }^{3,8-9}$ Pemberian Omega-3 juga akan menurunkan sekresi adipokin, seperti TNF- $\alpha$ dan IL-6, yang selanjutnya menurunkan protein fase akut dari hepar seperti C-RP. ${ }^{8-10}$

Penelitian tentang pengaruh intervensi Omega-3 oleh Caterina $\mathrm{dkk}^{11}$ melaporkan bahwa pemberian Omega-3 selama 12 minggu atau lebih meningkatkan pemakaian insulin melebihi 5\%, sedangkan pemberian di bawah 12 minggu kurang dari 5\%. Penelitian oleh Nobili dkk ${ }^{12}$ melaporkan bahwa pemberian Omega-3 selama 6 bulan meningkatkan sensitifitas insulin, di samping mengurangi jumlah lemak di hati dan menormalkan profil lemak itu sendiri. Muhammad $\mathrm{dkk}^{13}$ melaporkan bahwa telah terjadi penurunan C-RP setelah konsumsi Omega-3 sampai 40,3\% pada pasien dengan peningkatan kadar C-RP $>3 \mathrm{mg} / \mathrm{dL}$. Penelitian ini bertujuan untuk mengetahui pengaruh pemberian Omega-3 terhadap kadar C-RP pada remaja obesitas resistensi insulin.

\section{Metode}

Penelitian eksperimental dengan pemberian Omega-3 pada siswa SMU Kota Padang selama 12 minggu pada bulan Januari-Maret 2012. Populasi penelitian adalah siswa SMU obesitas resistensi insulin yang didapatkan dengan cara multistage random sampling. Kriteria inklusi adalah siswa obesitas resistensi insulin dan bersedia mengikuti penelitian. Kriteria eksklusi adalah anak yang menderita sakit berat sehingga membutuhkan perawatan di rumah sakit, menderita sindrom cushing, mengonsumsi obat penurun kadar lemak darah seperti statin dan fibrat, telah mengonsumsi suplemen Omega-3 selama 12 minggu atau lebih, mengalami trauma dan kecelakaan selama penelitian, mangkir dan tidak mau melanjutkan penelitian dikeluarkan dalam penelitian ini. Informed concent diminta kepada orang tua dan remaja bersangkutan sesuai dengan kode etik penelitian yang ditetapkan oleh Fakultas Kedokteran Universitas Andalas.

Batasan operasional pada penelitian ini adalah:

- Obesitas: nilai indeks massa tubuh (IMT) $\geq$ persentil 95 kurva BMI CDC 2000, didapatkan dari kalkulasi BB (dalam kg)/ $/ \mathrm{TB}^{2}$ (dalam meter). Pengukuran berat badan dengan menggunakan timbangan merk Detecto dengan akurasi $0,1 \mathrm{~kg}$. Tinggi badan diukur dengan menggunakan alat staturemeter merk Seca.

- Resistensi insulin: nilai HOMA-IR >3.16, didapatkan dari kalkulasi insulin darah puasa dalam $\mu \mathrm{IU} / \mathrm{L}$ dikali glukosa darah puasa dalam $\mathrm{mmol} / \mathrm{L}$ dibagi 22,5. Glukosa diukur dengan metode enzimatis, insulin diukur dengan metode electrohemiluminescence.

- C-Reactive Protein diukur dengan Metode CMIA (Chemiluminescent Immunometriz Assay), Immunolite 2000, buatan USA dengan sensitivitas $0,01 \mathrm{mg} / \mathrm{dL}$.

- Omega-3, dengan merk Blackmore, Odourless Fish Oil 1000 mg yang mengandung bentuk aktif Omega-3 (EPA dan DHA $250 \mathrm{mg}$ ) diberikan setiap hari selama 12 minggu.

Sampel darah pertama diambil untuk pemeriksaan kadar serum insulin dan glukosa darah setelah puasa 8 jam, untuk menghitung nilai HOMA-IR. Sampel juga dipakai untuk pemeriksaan C-RP dengan menyimpan pada suhu $-20^{\circ} \mathrm{C}$. Pemeriksaan dilakukan di Laboratorium Biomedik Fakultas Kedokteran Universitas Andalas. Pemberian kapsul suplemen makanan Omega-3 diberikan di sekolah setiap pagi, pada akhir intervensi (hari ke-91), dilakukan pengambilan darah vena $3 \mathrm{~mL}$ untuk pengukuran kadar C-RP ke-2. 
Semua data yang diperoleh dicatat dan diolah dengan uji statistik menggunakan Paired t-test $(\alpha=0,05)$.

\section{Hasil}

Didapatkan 38 orang populasi remaja obes resistensi insulin yang memenuhi kriteria inklusi dari 3 sekolah. Jumlah sampel yang ikut dalam penelitian ini 21 orang. Lebih dari separuh sampel berjenis kelamin laki-laki. Karakteristik sampel tertera pada Tabel 1.

Deskripsi masing-masing variabel yang diteliti tertera pada Tabel 2 berikut.

Tabel 1. Karakteristik sampel penelitian

\begin{tabular}{lcc}
\hline Karakteristik & Rerata \pm SD & $\mathrm{n}$ \\
\hline Umur (tahun) & $16 \pm 0,68$ & 21 \\
Jenis kelamin & & \\
$\quad$ Laki-laki & & 12 \\
$\quad$ Perempuan & & 9 \\
Berat badan $(\mathrm{kg})$ & $89,04 \pm 9,89$ & \\
Tinggi badan $(\mathrm{cm})$ & $165,30 \pm 6,84$ & \\
IMT $\left(\mathrm{kg} / \mathrm{m}^{2}\right)$ & $32,88 \pm 2,44$ & \\
\hline
\end{tabular}

Tabel 2 memperlihatkan bahwa nilai rerata kadar glukosa darah puasa remaja obes resistensi insulin $90,36 \pm 14,94 \mathrm{mg} / \mathrm{dL}$, kadar terendah $75,06 \mathrm{mg} / \mathrm{dL}$, dan kadar tertinggi $144,18 \mathrm{mg} / \mathrm{dL}$. Rerata kadar insulin darah remaja obes resistensi insulin 20,89 $\pm 4,19$ $\mu \mathrm{IU} / \mathrm{L}$, dengan kadar terendah 15,37 $\mu \mathrm{IU} / \mathrm{L}$ dan tertinggi $31,16 \mu \mathrm{IU} / \mathrm{L}$. Rerata nilai HOMA-IR adalah
$4,52 \pm 0,89$, dengan nilai terendah 3,34 dan tertinggi 7,13 (berada diatas nilai cut off point untuk resistensi insulin, yaitu 3,16). Rerata kadar C-RP remaja obesitas resistensi insulin sebelum dan sesudah pemberian Omega-3 tertera pada Tabel 3 berikut.

Rerata kadar C-RP pada kelompok uji sebelum pemberian Omega-3 adalah 8,69 $\pm 5,46 \mathrm{mg} / \mathrm{dL}$ dengan kadar terendah 6,00 mg/dL dan tertinggi $17,19 \mathrm{mg} /$ dL. Rerata kadar C-RP pada kelompok uji setelah pemberian Omega-3 selama 12 minggu adalah $6,41 \pm 4,77 \mathrm{mg} / \mathrm{dL}$ dengan kadar terendah $0,03 \mathrm{mg} / \mathrm{dL}$ dan tertinggi $15,82 \mathrm{mg} / \mathrm{dL}$. Uji statistik menunjukkan terdapat penurunan bermakna kadar C-RP sebelum dan sesudah intervensi dengan Omega-3 $(\mathrm{p}=0,018)$. Grafik boxplot di bawah ini memperlihatkan perubahan

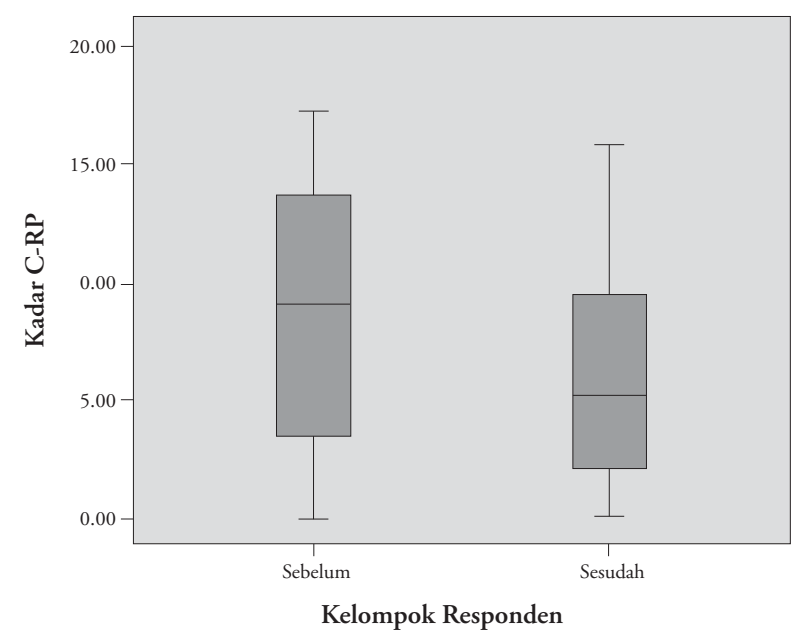

Gambar 1. Median perubahan kadar C-RP sebelum dan setelah intervensi Omega-3

Tabel 2. Deskripsi kadar gula darah puasa, insulin dan HOMA-IR

\begin{tabular}{lccc}
\hline Kadar serum & Rerata \pm SD & Minimum & Maksimum \\
\hline Glukosa puasa $(\mathrm{mg} / \mathrm{dL})$ & $90,36 \pm 14,94$ & 75,06 & 144,18 \\
Insulin $(\mu \mathrm{IU} / \mathrm{L})$ & $20,89 \pm 4,19$ & 15,37 & 31,16 \\
HOMA-IR & $4,52 \pm 0,89$ & 3,34 & 7,13 \\
\hline
\end{tabular}

Tabel 3. Kadar C-RP remaja obesitas resistensi insulin sebelum dan sesudah pemberian Omega-3

\begin{tabular}{lcccc}
\hline \multirow{2}{*}{ Pemberian Omega-3 } & \multicolumn{4}{c}{ Kadar C-RP $(\mathrm{mg} / \mathrm{dL})$} \\
\cline { 2 - 5 } & Rerata \pm SD & Minimum & Maksimum & \multirow{2}{*}{$\mathrm{p}^{*}$} \\
\hline Sebelum & $8,69 \pm 5,46$ & 6,00 & 17,19 & \multirow{2}{*}{0,018} \\
Sesudah & $6,41 \pm 4,77$ & 0,03 & 15,82 & \\
\hline
\end{tabular}

* Uji paired t-test 
median kadar C-RP sebelum dan sesudah intervensi.

Terdapat perubahan median kadar C-RP sebelum pemberian Omega-3 dengan sesudah pemberian selama 12 minggu, yaitu dari $8,98 \mathrm{mg} / \mathrm{dL}$ menjadi $5,19 \mathrm{mg} / \mathrm{dL}$.

\section{Pembahasan}

Didapatkan seorang subjek menderita diabetes mellitus. Rerata kadar insulin penelitian ini hampir sama dengan yang didapatkan oleh Verduci $\mathrm{dkk}^{14} \mathrm{di}$ Lisabon, yaitu 20,6 $\pm 6,3 \mu \mathrm{IU}$. Kadar glukosa darah saja bukanlah satu-satunya indikator seorang anak akan mengalami resisten insulin, tetapi juga dipengaruhi oleh kadar insulin. Kadar glukosa darah dan insulin yang tinggi akan menunjukkan suatu keadaan resistensi insulin yang berisiko untuk menimbulkan beberapa komplikasi, seperti diabetes mellitus, hipertensi, dan penyakit jantung koroner. ${ }^{15-16}$ Derajat resistensi insulin juga dipengaruhi oleh faktor etnis. Ethisham $\mathrm{dkk}^{17}$ melaporkan bahwa remaja Asia Selatan memiliki kadar insulin puasa yang lebih tinggi dan sensitivitas insulin ini kemungkinan berhubungan dengan adanya perbedaan komposisi tubuh antar etnis yang bersangkutan. Goran dkk ${ }^{18}$ melaporkan bahwa dengan persentase lemak tubuh yang sama, anak keturunan Hispanik lebih resisten insulin daripada anak keturunan Kaukasia.

Remaja obes resistensi insulin memiliki prevalensi komplikasi yang lebih besar dibandingkan remaja non resistensi insulin Oleh sebab itu, sangat penting untuk menangani obesitas lebih lanjut, termasuk intervensi diet disamping penurunan berat badan untuk mencegah risiko kardiovaskular secara dini. ${ }^{19}$

Caterina $\mathrm{dkk},{ }^{11}$ dalam penelitiannya di Italia, mendapatkan bahwa dengan memberikan suplemen Omega-3 selama 12 minggu dapat menurunkan kadar glukosa puasa $12 \%$. Giron dkk, ${ }^{20}$ dalam penelitiannya pada tikus diabetes, menunjukkan bahwa konsumsi Omega-3 menurunkan kadar gula darah dengan meningkatkan transporter Glut-4 yang akan menginduksi transport glukosa ke otot. Hussein $\mathrm{dkk},{ }^{21}$ dalam penelitiannya di Mecedonia, juga mendapatkan penurunan kadar glukosa puasa setelah pemberian Omega-3 pada tikus yang dibuat menderita diabetes mellitus. Penelitian ini tidak membandingkan kadar glukosa puasa sebelum dan setelah pemberian Omega-3. Walaupun pada penelitian ini hanya dilakukan pemeriksaan kadar glukosa puasa sebelum pemberian Omega-3, dapat diduga kadar glukosa puasa setelah pemberian Omega-3 juga mengalami penurunan. Hal tersebut disebabkan oleh pengaruh Omega-3 yang dapat meningkatkan sensitifitas terhadap insulin sehingga menurunkan kadar gula darah. ${ }^{3,21}$ Lopez dkk, ${ }^{22}$ dalam penelitiannya pada 201 anak obes, mendapatkan bahwa pemberian Omega-3 selama 12 minggu dapat menurunkan resistensi insulin dan kadar trigliserida.

Lama pemberian Omega-3 adalah 12 minggu dan diharapkan kadar insulin juga berkurang, tetapi penelitian ini tidak menilai pengaruh pemberian Omega-3 terhadap kadar insulin. Caterina dkk ${ }^{11}$ menyebutkan dengan pemberian Omega-3 selama 12 minggu atau lebih dapat meningkatkan pemakaian insulin melebihi 5\%, sedangkan pemberian di bawah 12 minggu peningkatan pemakaian insulin kurang dari $5 \%$. Nobili dkk ${ }^{12}$ mendapatkan bahwa pemberian Omega-3 selama 6 bulan dapat meningkatkan sensitifitas terhadap insulin, disamping dapat pula mengurangi jumlah lemak di hati dan menormalkan profil lemak itu sendiri.

Terdapat penurunan rerata kadar C-RP sebelum dan sesudah intervensi Omega-3. Penelitian terhadap kadar C-RP pada anak obesitas telah banyak dilakukan, antara lain Brasil $\mathrm{dkk}^{23}$ yang mendapatkan kadar C-RP yang lebih tinggi pada anak obesitas dibandingkan non obesitas. Lyon $\mathrm{dkk}^{24}$ yang menyimpulkan bahwa terdapat peningkatan kadar C-RP pada remaja obesitas. Demikian juga hasil penelitian Weiss $\mathrm{dkk}^{25}$ dan Zieske $\mathrm{dkk}^{26}$ yang mendapatkan kadar C-RP yang lebih tinggi pada sampel mereka yang mengalami obesitas.

Omega-3 berperan dalam proses inflamasi. Beberapa adipokin yang berperan dalam resisten insulin dan dihasilkan oleh sel lemak, antara lain TNF- $\alpha$, IL-6, resistin serta leptin. TNF- $\alpha$, dan IL-6 selanjutnya akan merangsang hati untuk memproduksi C-RP. ${ }^{3,6,8}$ Dengan pemberian Omega-3, proses inflamasi akan berkurang yang selanjutnya akan mengurangi produksi sitokin proinflamasi dan protein fase akut seperti C-RP. ${ }^{9}$ Kadar C-RP pada remaja obesitas resisten insulin penelitian ini lebih tinggi dari nilai normal (di atas $1 \mathrm{mg} / \mathrm{dL}$ ). Rerata selisih kadar C-RP sebelum dan sesudah pemberian Omega-3 adalah 2,28 $\pm 0,69$ $\mathrm{mg} / \mathrm{dL}$. Setelah intervensi Omega-3, terdapat penurunan 26,4\% kadar C-RP pada anak dengan kadar tertinggi sebelum intervensi. Penurunan kadar C-RP ini hampir sama dengan hasil penelitian Muhammad 
dkk, ${ }^{13}$ pada pasien dengan peningkatan kadar C-RP $>3 \mathrm{mg} / \mathrm{dL}$, terjadi penurunan C-RP setelah konsumsi Omega-3 sampai 40,3\% dibandingkan kelompok plasebo (penurunan 16,4\%). Tsitouras $\mathrm{dkk}^{27}$ juga mendapatkan terjadinya penurunan C-RP setelah konsumsi Omega-3. Demikian juga penelitian oleh Puglisi $\mathrm{dkk}^{28}$ yang mendapatkan penurunan yang signifikan dari kadar C-RP setelah konsumsi Omega-3.

Penelitian ini masih memiliki kelemahan, di antaranya jumlah sampel yang masih sedikit dan tidak dilakukan perbandingan dengan kelompok kontrol (remaja obesitas resistensi insulin) yang tidak diberikan Omega-3. Selain itu, tidak dilakukan pembatasan diet makanan, terutama anti oksidan dan aktivitas harian pada masing-masing sampel penelitian yang ikut memengaruhi hasil penelitian.

\section{Kesimpulan}

Remaja obes resistensi insulin mempunyai rerata kadar glukosa puasa dan kadar insulin yang lebih tinggi dibandingkan nilai normal. Pemberian suplemen Omega-3 pada remaja obes resisten insulin dapat menurunkan proses inflamasi, ditandai penurunan kadar C-RP secara bermakna.

\section{Ucapan terima kasih}

Terimakasih penulis ucapkan kepada kepala bagian, kepala program studi, dan seluruh staf Ilmu Kesehatan Anak RS Dr. M. Djamil Padang yang telah menyempurnakan penulisan ini, serta kepada kepala sekolah dan seluruh guru yang telah ikut membantu dalam penelitian ini.

\section{Daftar pustaka}

1. Subardja D, Cahyono HA, Moelyo AG. Obesitas pada anak. Dalam: Batubara JRL, Tridjaja B, Pulungan AB, penyunting. Buku Ajar Endokrinologi Anak. Jakarta: UKK Endokrinologi Anak dan Remaja IDAI; 2010.

2. Fryar CD, Carroll MD, Ogden CL. Prevalence of obesity among children and adolescents: United States, trends 1963-1965 through 2009-2010. Diakses pada 14 Juli 2013. Diunduh dari : http://www.cdc.gov/nchs/data/hestat/ obesity_child_07_08/obesity_child_07_08.htm.

3. Kalupahana NS, Claycombe KJ, Moustaid-Moussa N. (n-3) fatty acids alleviate adipose tissue inflammation and insulin resistance: mechanistic insights. Adv Nutr 2011;2:304-16.

4. Das UN. Is metabolic syndrome $\mathrm{x}$ an inflammatory condition. Exp Biol Med 2002;227:989-97.

5. Freedman DS, Dietz WH, Srinvasan SR, Berenson GS. The relation of overweight to cardiovascular risk factors among children and adolescent: the Bogalusa Heart Study. Pediatrics 1999;103:1175-82.

6. Despres JP. Abdominal obesity: the most prevalent cause of the metabolic syndrome and related cardiometabolic risk. European Heart J 2006;8:B4-12.

7. Giugliano D, Ceriello A, Esposito K. Are there specific treatments for metabolic syndrome? Am J Clin Nutr 2008;87:8-11.

8. Drevon CA. Omega-3 fatty acids-metabolism and mechanism of action of essential fatty acids. Diakses pada Agustus 2011. Diunduh dari: http://Omega-3. Möllers_orig.indd.

9. Simopoulos AP. Omega-3 fatty acids in inflamation and autoimmune diseases. J Am Coll Nutr 2001;21:495505.

10. Masterton GS, Pleuris JN, Hayes DC. Review article: Omega-3 fatty acids a promising novel therapy for nonalcoholic fatty liver disease. Aligment Pharmacol Ther 2009;10:1365-2036.

11. Caterina R, Bertolotto A, Madonna R, Schmidt EB. n-3 Fatty acids in the treatment of diabetic patients. Diabetic Care 2007;30:1012-21.

12. Nobili V, Bedogni G, Aksi A, et al. Docosahexaenoid acid supplementation decreases liver but content in children with non-alcoholic fatty liver disease:double blind randomized controlled clinical trial. Arch Dis Child 2011:2-4.

13. Muhammad K, Morledget, Saachar R. Treatment with -3 fatty acids reduces serum C-reactive protein concentration. Clin Lipidol 2011;6:723-29.

14. Verduci E, Seaglioni S, Agosonic. The relationship of insulin resistence with SNP 276 G>T at adiponectin gene and plasma long-chain polyunsaturated fatty acids in obese children. Pediatr Res 2009;66:346-8.

15. Weiss R, Kaufman FR. Metabolic complications of childhood obesity: identifying and mitigating the risk. Diabetes care 2008;31:S310-6.

16. Keskin M, Kurtoglu S, Kendirci M, Atabek ME, Yazici C. Homeostasis model assesement is more reliable than the fasting glucose/insulin ratio for assessing insulin resistance among obese children and adolescents. Pediatrics 2005;115:e500-3. 
17. Ehtisham S, Crabtree N, Clark P, Shaw N, Barrett T. Ethnic differences in insulin resistance and body composition in United Kingdom adolescent. J Clin Endocrinol Metab 2005;90:3963-9.

18. Goran MI, Bergman RN, Cruz MI, Watanabe RM. Insulin resistance and associated compensatory responses in African American and Hispanic children. Diabetes Care 2002;25:2353.

19. Sinaiko AR, Steinberger J, Moran A, Hong CP, Prineas RJ, Jacobs DR. Influence of insulin resistance and body mass index at age 13 on systolic blood pressure, triglycerides and high-density lipoprotein cholesterol at age 19. Hypertension 2006;48:730-6.

20. Giron MD, Salto R, Hortelano P, Periago JL, Vargas AM, Suarez MD. Increased diaphragm expression of GLUT4 in control and streptozotocin-diabetic rats by fish oil-supplemented diets. Lipids 1999;34:801-7.

21. Hussein J, Motafa E, El - Waseef M, El-Khayat Z, Badawy E, Medhat D. Effect of Omega-3 fatty acids on erytrocyte membrane in diabetic rats. Maacedonian J Med Sciences 2011;4:234-9.

22. Lopez CJ, Klunder MK, Azcarte AM, Huerta SF. Omega-3 polyunsaturated fatty acids reduce insulin resistance and trygliserides in obese children and adolescents [abstract]. Pediatric Diabetes 2013;14:377-83.

23. Brasil AR, Norton RC, Rossetti MB, Leoao E, Mendes RP. C-reactive protein as an indicator of low intensity inflammation in children and adolescents with and without obesity. J Pediatr 2007;83:477-80.

24. Lyon CJ, Law RE, Hsueh WA. Mini review: adiposy, inflammation and atherogenesis. Endocrinology 2003;144:2195-200.

25. Weiss R, Dziura J, Burgert TS. Obesity and metabolic syndrome in children and adolescents. N Engl J Med 2004;350:2362-74.

26. Zieske AW, Tracy RP, McMahan A. Elevated serum C-reactive protein levels and advanced atherosclerosis in youth. Arterioscler Thromb Vasc Biol 2005;25:1237-43.

27. Tsitouras PD, Gucciardo F, Salbe AD, Heward C, Harman SM. High Omega-3 fat intake improves insulin sensitivity and reduces CRP and IL6, but does not affect other endocrine axes in healthy older adults. Horm Metab Res 2008;40:199-205.

28. Puglisi MJ, Fernandez ML. Modulation of C-reactive protein, tumor necrosis factor- $\alpha$, and adiponectin by diet, exercise, and weight loss. J Nutr 2008;138:2293-6. 